\title{
Facial Aesthetic Angles of the Ibo and Yoruba Ethnic Groups of Nigeria
}

\author{
Chisom Favor Eliakim-Ikechukwu ${ }^{1 *}$, Augustine Sylvester Ekpo ${ }^{2}$, Mfon Etika $^{3}$, \\ Churchill Ihentuge ${ }^{4}$, Otu Effiong Mesembe ${ }^{5}$. \\ ${ }^{1,2,3,5}$ Department of Anatomy, Faculty of Basic Medical Sciences, University of Calabar, Cross River State, \\ Nigeria. \\ ${ }^{4}$ Department of Anatomy, Imo State University, Owerri, Nigeria.
}

\begin{abstract}
Lateral facial photographs of 276 Ibo subjects (184 males and 92 females) and 201 Yoruba subjects (106 males and 95 females) were taken with a digital lens camera. The aesthetic angles were traced out from the photographs and measured.

The Ibo males had mean values of $37.8^{0} \pm 0.45$ for nasofacial angle, $127.1^{0} \pm 0.55$ for nasofrontal angle, $76.1 \pm 0.89$ for nasolabial angle $125.90 \pm 0.39$ for nasomental angle and $88.6 \pm 0.33$ for mentocervical angle. The Ibo females had mean values of $36.3^{\circ} \pm 0.37$ for nasofacial angle, $131.7^{0} \pm 0.53$ for nasofacial angle, $82.5 \pm 1.45$ for nasolabial angle, $125.1^{0} \pm 0.92$ for nasomental angle and $87.5^{\circ} \pm 0.65$ for mentocervical angle. The Yoruba males had mean values of $37.3^{\circ} \pm 1.76$ for nasofacial angle, $127.9^{\circ} \pm 0.69$ for nasofrontal angle, $77.0^{\circ} \pm 128$ for nasolabial angle, $125.6^{\circ} \pm 0.54$ for nasomental angle and $85.9^{\circ} \pm 0.68$ for mentocervicial angle. The Yoruba females had mean values of $35.5^{\circ} \pm 0.38$ for nasofacial angle, $134.3^{\circ} \pm 0.57$ for nasofrontal angle, $84.0^{\circ} \pm 1.36^{\circ}$ for nasolabial angle, $126.8^{0} \pm 0.68$ for nasomental angle and $85.6^{\circ} \pm 0.71$ for mentocervical angle.

There was significant sexual and ethnic differences at $P<0.05$ using some of the angles.
\end{abstract}

Keywords: Mentocervical angle,nasofacial angle, nasofrontal angle, nasolabial angle, nasomental angle.

\section{Introduction}

Over the years, it has been a difficult task to define the term beauty. To Plato and Aristotle, beauty meant symmetry, harmony and geometry. In the fifth century BC, the Greek Sculptor, Polyclitus defined perfect beauty as mutual harmony of all parts, such that harmonic proportions were held to be beautiful in themselves, independent of any observer[1]. Nevertheless, although every generation's concept of beauty is influenced by social and cultural factors, the aesthetic canons have withstood the test of time[1].

As illustrated by the work of artists and anatomists of the $17^{\text {th }}$ to the $19^{\text {th }}$ centuries, the concept of beauty and "normal" facial proportions has changed with time. Furthermore, as population becomes more heterogeneous, new facial proportions have emerged from interracial mixing. It is now apparent that what has been considered beautiful and acceptable as the norm for one culture may be different for another. Inherently, the notion of a single aesthetic standard and beauty is grossly inadequate and naive. What is required is a new model of aesthetic standards and beauty that is unique to different ethnic groups to better fit their facial skeletal and skin profile and culture[2].

Morphological features of different races and ethnic groups are not randomly distributed but appear in geographical cluster thus there is a need for facial study of different ethnic groups to establish specific anthropometric data for populations with different ethnic backgrounds[3]. Facial traits are largely influenced by race, ethnic group, age, sex and culture[4].

The face is divided into aesthetic units that are further divided into subunits. The major units that are classically defined for facial analysis include the forehead, eyes, nose, lips, chin, ears and neck[1]. Because the nose is the central and most prominent aesthetic unit of the face, it is always analyzed in relationship to other facial structures most importantly, the chin, the lips and the eyebrows. Currently, major parameters used in facial aesthetics are based on Powell and Humpherys[5]. These authors formulated suitable relationships between the face and the nose and defined facial angles. The facial angles include the nasofacial, the nasofrontal, the nasolabial, the nasomental and the mentocervical angles.

This study therefore intends to report a baseline data of aesthetic facial angles among the Ibo and Yoruba ethnic groups of Nigeria and also to determine any sex or ethnic variations.

\section{Materials And Methods}

Four hundred and seventy-seven subject (290 males and 187 females) within 18-35 years age range. Demographical data including age, place of birth, length of stay in the place and parental and grandparental heritage was got. Subjects with facial asymmetry, congenital abnormalities, facial fractures or maxillofacial surgeries were excluded from the study. 
Subjects were made to sit straight with their heads in anatomical position. Lateral photographs of their faces were taken against a white background using a digital lens camera one meter away from the subjects. The photographs were printed out and used for the study. Some soft tissue landmarks were made on each of the photographs namely, the glabella, Nasion, Subnasale, Menton, Pogonion and Subcervicale.

Reksodiputro et al.[6] clearly describes how the aesthetic angles are created. The nasofrontal (NFR) angle is between glabella-nasion line and nasion-nasal tip line. The range is expected to be $115^{\circ}-135^{\circ}$. The nasofacial (NFA) angle is between vertical line just touching the forehead at the glabella and the Pogonion (facial plane), intersected by nasion - nasal tip line. The range varies form $30^{\circ}-40^{\circ}$. The nasolabial (NLA) angle is between the nasal tip- subnasale line and subnasale-labium superioris line. It should measure $95^{\circ}-110^{\circ}$ in women and $90^{\circ}-95^{\circ}$ in men. The nasomental (NM) angle is between nasion-nasal tip line and nasal tip-menton line. The range is $120^{\circ}-132^{0}$. The mentocervical (MC) angle is between the glabella-pogonion line and the menton-cervical point line. Ideally measures $80^{\circ}-95^{\circ}[1]$.

Comparison of the means of the different sexes and ethnic groups was done using the student $\mathrm{t}$-test at a significant level of $\mathrm{p} \leq 0.05$.

\section{Results}

Table 1: Aesthetic facial angles of the two ethnic groups (Ibo and Yoruba)

\begin{tabular}{|l|l|l|l|l|}
\hline \multirow{4}{*}{ Angles } & \multicolumn{4}{|c|}{ Ethnic Group } \\
\cline { 2 - 5 } & $\begin{array}{l}\text { Ibo } \\
\text { Mean } \pm \text { SEM } \\
\text { (in degrees ) }\end{array}$ & $\begin{array}{l}\text { Female }(\mathrm{n}=92) \\
\text { Mean } \pm \text { SEM } \\
\text { (in degrees })\end{array}$ & $\begin{array}{l}\text { Male }(\mathrm{n}=106) \\
\text { Mean } \pm \text { SEM } \\
\text { in degrees })\end{array}$ & $\begin{array}{l}\text { Female }(\mathrm{n}=95) \\
\text { Mean } \pm \text { SEM } \\
\text { (in degrees })\end{array}$ \\
\hline NFR & $127.1^{0} \pm 0.55$ & $131.7^{0} \pm 0.53$ & $127.9^{0} \pm 0.69$ & $134.3^{0} \pm 0.57$ \\
\hline NFA & $37.8^{0} \pm 0.45$ & $36.3^{0} \pm 0.37$ & $37.3^{0} \pm 1.76$ & $35.5^{0} \pm 0.38$ \\
\hline NLA & $76.1^{0} \pm 0.89$ & $82.5^{0} \pm 1.45$ & $77.0^{0} \pm 1.28$ & $84.0^{0} \pm 1.36$ \\
\hline NM & $125.9^{0} \pm 0.39$ & $125.1^{0} \pm 0.92$ & $125.6^{0} \pm 0.54$ & $126.8^{0} \pm 0.68$ \\
\hline MC & $88.6^{0} \pm 0.33$ & $87.5^{0} \pm 0.65$ & $85.9^{0} \pm 0.68$ & $85.6^{0} \pm 0.71$ \\
\hline
\end{tabular}

$\mathrm{n}=$ number of subjects; SEM = standard Error of Mean

In table 1, the means of the different angles are outlined for the different sexes and ethnic groups. For the Ibo ethnic group, the nasofrontal angle for the males and females are $127.1^{0} \pm 0.55$ and $131.7^{0} \pm 0.53$ respectively; nasofacial angle of $37.8^{0} \pm 0.45$ and $36.3^{\circ} \pm 0.37$ for males and females respectively; nasolabial angles of $76.1^{0} \pm$ 0.89 and $82.5^{0} \pm 1.45$ for males and females respectively; nasomental angles of $125.9^{0} \pm 0.39$ and $125.1^{0} \pm 0.92$ for males and females respectively and mentocervical angles of $86.6^{\circ} \pm 0.33$ and $87.5^{\circ} \pm 0.65$ for males and females respectively. For the males and females of the Yoruba ethnic group, nasofrontal angle is $127.9^{0} \pm 0.69$ and $134^{0} 3^{0} \pm 0.57$ respectively; nasofacial angle is $37.3^{\circ} \pm 1.76$ and $35.5^{\circ} \pm 0.38$ respectively; nasolabial angle is $77.00 \pm 1.28$ and $84.0^{\circ} \pm 1.36$ respectively; nasomental angle is $125.6^{0} \pm 0.54$ and $126.8 \pm 0.68$ respectively and the mentocervical angle is $85.9^{0} \pm 0.68$ and $85.6^{\circ} \pm 0.71$ respectively.

Table 2: Comparison of the means of both sexes of the Ibo ethnic group

\begin{tabular}{|c|c|c|c|c|c|}
\hline \multirow[t]{3}{*}{ Angles } & \multirow[t]{3}{*}{ Sex } & \multirow{3}{*}{$\begin{array}{l}\text { Mean } \pm \text { SEM } \\
\text { (in degrees ) }\end{array}$} & \multirow{3}{*}{$\mathrm{SEM}_{\mathrm{D}}$} & & \multirow[b]{2}{*}{$(\mathrm{P}=0.05)$} \\
\hline & & & & t-ratio & \\
\hline & & & & Calculated & Table \\
\hline NFR* & $\begin{array}{l}\text { Male } \\
\text { Female }\end{array}$ & $\begin{array}{l}127.1^{0} \pm 0.55 \\
131.7^{0} \pm 0.53\end{array}$ & 0.76 & 6.052 & 1.96 \\
\hline NFA & $\begin{array}{l}\text { Male } \\
\text { Female }\end{array}$ & $\begin{array}{l}37.8^{0} \pm 0.45 \\
36.3^{0} \pm 0.37\end{array}$ & 0.58 & 1.55 & 1.96 \\
\hline NLA * & $\begin{array}{l}\text { Male } \\
\text { Female }\end{array}$ & $\begin{array}{l}76.1^{0} \pm 0.89 \\
82.5^{0} \pm 1.45\end{array}$ & 1.70 & 3.74 & 1.96 \\
\hline NM & $\begin{array}{l}\text { Male } \\
\text { Female }\end{array}$ & $\begin{array}{l}125.9^{0} \pm 0.39 \\
125.1^{0} \pm 0.92\end{array}$ & 0.99 & 0.81 & 1.96 \\
\hline $\mathrm{MC}$ & $\begin{array}{l}\text { Male } \\
\text { Female }\end{array}$ & $\begin{array}{l}88.6^{0} \pm 0.33 \\
87.5^{0} \pm 0.65\end{array}$ & 0.73 & 1.50 & 1.96 \\
\hline
\end{tabular}

* Significant at $\mathrm{P} \leq 0.05 ; \mathrm{SEM}_{\mathrm{D}}-$ Standard Error of Mean Deviation. 
Table 3: Comparison of the means of both sexes of the Yoruba ethnic group

\begin{tabular}{|c|c|c|c|c|c|}
\hline \multirow[t]{2}{*}{ Angles } & \multirow[t]{2}{*}{ Sex } & \multirow{2}{*}{$\begin{array}{l}\text { Mean } \pm \text { SEM } \\
\text { (in degrees ) }\end{array}$} & \multirow[t]{2}{*}{$\mathrm{SEM}_{\mathrm{D}}$} & t-ratio & $(\mathrm{P}=0.05)$ \\
\hline & & & & Calculated & Table \\
\hline NFR* & $\begin{array}{l}\text { Male } \\
\text { Female }\end{array}$ & $\begin{array}{l}127.1^{0} \pm 0.69 \\
134.3 \pm 0.57\end{array}$ & 0.89 & 7.10 & 1.96 \\
\hline NFA & $\begin{array}{l}\text { Male } \\
\text { Female }\end{array}$ & $\begin{array}{l}37.3 \pm 1.76 \\
35.5 \pm 0.38\end{array}$ & 1.80 & 1.00 & 1.96 \\
\hline NLA * & $\begin{array}{l}\text { Male } \\
\text { Female }\end{array}$ & $\begin{array}{l}77.0 \pm 1.28 \\
84.0 \pm 1.36\end{array}$ & 1.87 & 3.74 & 1.96 \\
\hline NM & $\begin{array}{l}\text { Male } \\
\text { Female }\end{array}$ & $\begin{array}{l}125.6 \pm 0.54 \\
126.8 \pm 0.68\end{array}$ & 0.87 & 1.38 & 1.96 \\
\hline $\mathrm{MC}$ & $\begin{array}{l}\text { Male } \\
\text { Female }\end{array}$ & $\begin{array}{l}85.9 \pm 0.68 \\
85.6 \pm 0.71\end{array}$ & 0.98 & 0.33 & 1.96 \\
\hline
\end{tabular}

$*$ Significant at $\mathrm{P} \leq 0.05 ; \mathrm{SEM}_{\mathrm{D}^{-}}$Standard Error of Mean Deviation.

Table 4: Comparison of the means of the male subjects of the two ethnic groups.

\begin{tabular}{|c|c|c|c|c|c|}
\hline \multirow[t]{2}{*}{ Angles } & \multirow{2}{*}{$\begin{array}{l}\text { Ethnic } \\
\text { Group }\end{array}$} & \multirow{2}{*}{$\begin{array}{l}\text { Mean } \pm \text { SEM } \\
\text { (in degrees ) }\end{array}$} & \multirow[t]{2}{*}{$\mathrm{SEM}_{\mathrm{D}}$} & t-ratio & $(\mathrm{P}=0.05)$ \\
\hline & & & & Calculated & Table \\
\hline NFR & $\begin{array}{l}\text { Ibo } \\
\text { Yoruba }\end{array}$ & $\begin{array}{l}127.1 \pm 0.55 \\
127.9 \pm 0.69\end{array}$ & 0.88 & 0.91 & 1.96 \\
\hline NFA & $\begin{array}{l}\text { Ibo } \\
\text { Yoruba }\end{array}$ & $\begin{array}{l}37.8 \pm 0.69 \\
37.3 \pm 1.76\end{array}$ & 1.80 & 0.27 & 1.96 \\
\hline NLA & $\begin{array}{l}\text { Ibo } \\
\text { Yoruba }\end{array}$ & $\begin{array}{l}76.1 \pm 0.89 \\
77.0 \pm 1.26\end{array}$ & 1.55 & 0.58 & 1.96 \\
\hline NM & $\begin{array}{l}\text { Ibo } \\
\text { Yoruba }\end{array}$ & $\begin{array}{l}125.9 \pm 0.39 \\
125.6 \pm 0.54\end{array}$ & 0.66 & 0.50 & 1.96 \\
\hline $\mathrm{MC}^{*}$ & $\begin{array}{l}\text { Ibo } \\
\text { Yoruba }\end{array}$ & $\begin{array}{l}88.6 \pm 0.33 \\
85.9 \pm 0.68\end{array}$ & 0.75 & 3.60 & 1.96 \\
\hline
\end{tabular}

* Significant at $\mathrm{P} \leq 0.05$

Table 5: Comparison of the means of the females of the two ethnic group

\begin{tabular}{|c|c|c|c|c|c|}
\hline \multirow[t]{2}{*}{ Angles } & \multirow{2}{*}{$\begin{array}{l}\text { Ethnic } \\
\text { Group }\end{array}$} & \multirow{2}{*}{$\begin{array}{l}\text { Mean } \pm \text { SEM } \\
\text { (in degrees ) }\end{array}$} & \multirow[t]{2}{*}{$\mathrm{SEM}_{\mathrm{D}}$} & t-ratio & $(\mathrm{P}=0.05)$ \\
\hline & & & & Calculated & Table \\
\hline NFR* & $\begin{array}{l}\text { Ibo } \\
\text { Yoruba }\end{array}$ & $\begin{array}{l}131.7 \pm 0.53 \\
134.3 \pm 0.57\end{array}$ & 0.78 & 3.33 & 1.96 \\
\hline NFA* & $\begin{array}{l}\text { Ibo } \\
\text { Yoruba }\end{array}$ & $\begin{array}{l}36.3 \pm 0.37 \\
35.5 \pm 0.38\end{array}$ & 0.53 & 2.64 & 1.96 \\
\hline NLA & $\begin{array}{l}\text { Ibo } \\
\text { Yoruba }\end{array}$ & $\begin{array}{l}82.5 \pm 1.45 \\
84.0 \pm 1.36\end{array}$ & 1.99 & 0.75 & 1.96 \\
\hline $\mathrm{NM}$ & $\begin{array}{l}\text { Ibo } \\
\text { Yoruba }\end{array}$ & $\begin{array}{l}125.1 \pm 0.92 \\
126.8 \pm 0.68\end{array}$ & 1.14 & 1.50 & 1.96 \\
\hline $\mathrm{MC}^{*}$ & $\begin{array}{l}\text { Ibo } \\
\text { Yoruba }\end{array}$ & $\begin{array}{l}87.5 \pm 0.65 \\
85.9 \pm 0.71\end{array}$ & 0.96 & 1.98 & 1.96 \\
\hline
\end{tabular}

* Significant at $\mathrm{P} \leq 0.05$

Tables 2-5 show comparisons of the different means. Table 2 shows a significant $(\mathrm{p}<0.05)$ difference in means of the nasofrontal and nasolabial angles between the males and females of the Ibo ethnic group. 
Also in table 3 , there exist a significant $(\mathrm{P}<0.05)$ difference in means in the nasofrontal and nasolabial angles in the Yoruba ethnic groups.

Comparison of the means in males (Table 4) of the two ethnic groups only showed significant $(\mathrm{p}<0.05)$ difference with the mentocervical angle. In table 5, comparison of means in females of the two ethnic groups showed significant $(\mathrm{P}<0.05)$ variation with the nasofrontal, nasofacial and mentocervical angles.

\section{Discussion}

In this study, the values for the different angles of facial aesthetics fell within the expected ranges recorded by Powell and Humphreys[5] except the nasolabial angle for the two sexes and the two ethnic groups studied. An acute nasolabial angle $\left(83.1^{\circ}\right)$ has also been reported among the African American man[7]. Reksodiputro et al.[6] also recorded a smaller nasolabial angle $\left(92.81^{\circ}\right)$ among the Javanese female than in the white women. It appears the acuteness of this angle in the ethnic groups studied is as result of a more prominent maxillary prominence.

Gender differences seen in this study has also been reported by other researchers including Oghenemavwe et. al. [8] in his work with the Urhobo ethnic group of Nigeria, Anibor et al. [9] in his work with the Itsekiri ethnic group of Nigeria and two studies in Mexico[10]. In an earlier work by Anibor and Okumagba[11] among the Ibo ethnic group, no statistical gender difference was observed which is in disagreement with this present study.

Differences in the two ethnic groups is also in agreement with some earlier works[2][8][12][13].

From this study, the nasofacial and nasomental angles is not parameter to differentiate between gender and ethnic groups. Sim et al.[13] also reported similar nasomental and nasofacial angles between the Chinese and Whites. Differences in aesthetic facial angle is believed to revolve around the nose[7].

\section{Conclusion}

In conclusion, the different aesthetic facial angles have been documented in this study. The nasofrontal and nasolabial angles are useful tools for gender differentiation while the mentocervical angle is useful in ethnic differentiation. Nasofrontal and nasofacial angles can also be used in differentiating the females into the two ethnic groups studied.

\section{References}

[1] P. W. Flint, B. H. Haughey, V. J. Lund, J. K. Niparko, M. A. Richardson, K. T. Robbins, J. R. Thomas. Cummings Otolaryngology- Head and Neck Surgery, $5^{\text {th }}$ edition, 2010, Vol.1. Mosby Elsevier.

[2] K. S. Choe, A. P Sclafani, J. A. Litner, G-P. Yu, T. Romo. The Korean American Woman's face. Anthropometric measurements and quantitative analysis of facial aesthetics. Arch. Facial Plast.Surg. 2004,6: 244-252.

[3] K. Krishna and R. Kumar. Determination of stature from cephalofacial dimensions in a North Indian population. Legal Med. 2007, 9(3): 128-133.

[4] N. A.Mandall, J. F. McCord, A. S. Blinkhor, H.V. Worthington, K.D. O.Brien. Perceived aesthetics impact of mal-occlusion and oral self-perceptions in 14-15years old Asian and caucasion children in Great Manchester. Eup.J. of Orthod. 2000, 21:175-183.

[5] N. Powell and B. Humphreys. Proportions of aesthetic face. Thieme-stratton, 1984, New York.

[6] M. H.Reksodiputro, T. Koento, Boedhihartono, A. P. Sclafani. Facial anthropometric analysis of the Javanese female. Arch. Facial plast. Surg.,2009, 11 (5): 347-349.

[7] J. P. Porter, J. The average African American Male Face. An anthropometric analysis. Arch. Facial Plast. Surg.2004, 6: 78-81.

[8] E. L. Ogbenemavwe, A. E. Osunwoke, S. K. Ordu, O. Omovigho. Photometric analysis of soft tissue Facial Profile of Adult Urhobos. Asian J. Med. Scs.,2010, 2 (6): 248-252.

[9] E. Anibor, M. Okumagba,G. Avwioro. Photometric facial analysis of the Itsekiri ethnic group in Nigeria. Advances in Applied Science Research,2011, 2 (1): 145-148.

[10] C. Lara. Cephalometric norms according to the Harvold's analysis. Int. J.Odontostomat. 2009, 3(1)33-39.

[11] E. Anibor and M. Okumagba. Photometric Facial analysis of the Ibo ethnic group in Nigeria. Archives of Applied Science Research, 2010, 2(6):219-222

[12] S. K. Jain, C. Anand, S. K. Ghosh. Photometric Facial Analysis-A Baseline Study. J. Anat.Soc. 2004,53 (2): 7-12.

[13] R. S. T. Sim, J. D. Smith, A. S. U. Chan. Comparison of the aesthetic facial proportions of Southern Chinese and White women. Arch. Facial Plast. Surg., 2000, 2:113-120. 